\title{
Scleroderma septentrionale, a new gasteromycete from North-European sand dunes
}

\author{
MIKAEL JEPPSON
}

\begin{abstract}
JEPPSON, M. 1998: Scleroderma septentrionale, a new gasteromycete from NorthEuropean sand dunes. - Karstenia 38:37-43. Helsinki. ISSN 0453-3402

A new species of the Sclerodermatales (Basidiomycota), Scleroderma septentrionale Jeppson, is described from sand dunes and sandy heaths in northern Europe. A table showing diagnostic characters in European species of Scleroderma sect. Scleroderma is presented.
\end{abstract}

Key words: Scleroderma septentrionale, Gasteromycetes, North Europe, taxonomy

Mikael Jeppson, Lilla Håjumsgatan 4, S-461 35 Trollhättan, Sweden

\section{Introduction}

Scleroderma Pers. is a gastroid genus with a worldwide distribution. Guzmán (1970) in his monograph of the genus divided it into three sections based on microcharacters in spores and hyphae. One of these sections, sect. Scleroder$m a$, is characterized by spores showing a distinct reticulation and by having nodose-septate peridial hyphae. Scleroderma bovista Fr., S. citrinum Pers. and $S$. meridionale Demoulin \& Malençon are well-known European representatives of this section.

In this paper a new species in the section Scleroderma is proposed, viz. $S$. septentrionale. The new taxon is a characteristic species met with on sand dunes and sandy heaths in northern Europe. It shows a more northerly distribution than any other species of the genus. Previous records of this taxon treat it as a sand form of either $S$. aurantium $(=S$. citrinum) or S. bovista .

\section{Material and methods}

The study is based on a total of approximately 80 collections preserved in the herbaria of $\mathrm{H}, \mathrm{LD}$, OULU,
REYK, S, TUR, UME and UPS. The author's private herbarium is designated M.J. Drawings and descriptions were made from dried specimens. Microscopic studies were carried out in an ordinary light microscope and the samples were mounted in lactophenol. Spore sizes were measured excluding the spore wall ornamentation. The nomenclature of vascular plants is in accordance with Mossberg et al. (1992).

Scleroderma septentrionale Jeppson, n. sp. Figs. 1-4

Scleroderma macrorhizon Wallroth sensu Guzmán (1970) pro parte

S. bovista Fr. sensu Andersson (1950) pro parte, Eriksson (1964), Rautavaara (1953)

S. aurantium Pers. sensu Arwidsson (1936)

Carposoma maturum subglobosum 20-60 mm diam., pseudostipite compacto vel fasciculato ad $80 \times 30 \mathrm{~mm}$. Peridium tenue, ad $1 \mathrm{~mm}$ latum, pallide ochraceum vel luteo-brunneum, in squamulas subtiles diffractum. Hyphae fibulatae. Dehiscentia apicalis irregularis. Gleba maturitate griseobrunnea quandoque olivaceobrunnea. Sporae globosae vel subglobosae, (7-)9-11(15) $\mu \mathrm{m}$ diam., reticulatae. Carposoma maturum epigaeum vel semi-hypogaeum. 


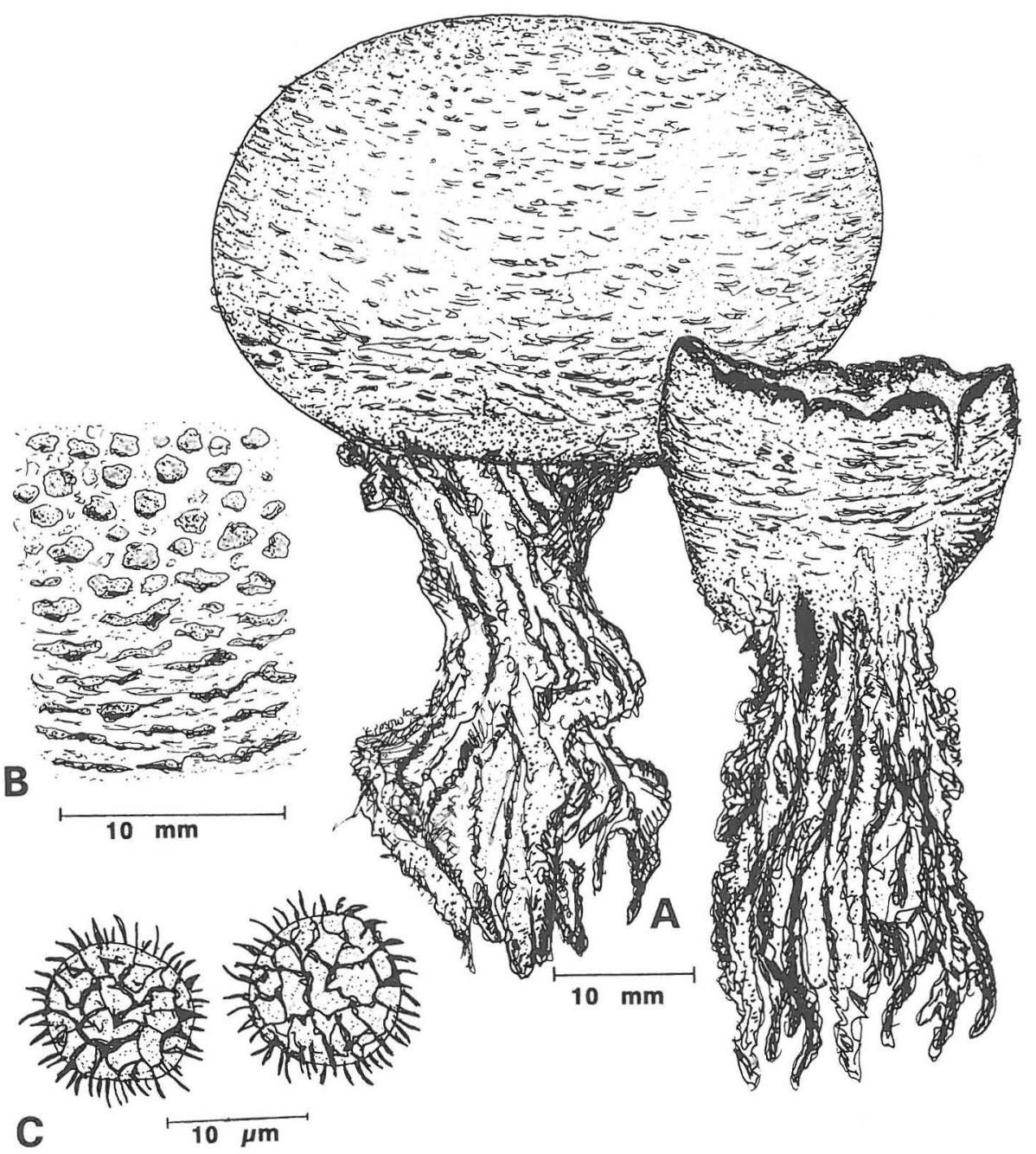

Fig. 1. Scleroderma septentrionale. A) Fruitbodies. B) Detail of peridium. C) Spores. (Sweden, Nb, Piteå, 10.IX.1986 J. Nitare, S).

In locis arenosis, praecipue in thiniis litoralibus Europae septentrionalis.

Holotypus: Finland, Oulun Pohjanmaa, Haukipudas, Isoniemi, Saukkoperä, 18.IX.1984 T. Ulvinen, E. Ohenoja \& K. Kalamees (OULU).

Fruitbody subglobose, 20-60 mm in diametre. Twinned fruitbodies sometimes occur (Fig. 2 A, B, G). Pseudostipe prominent, 30-80 × 10-30 mm, usually widest at the base, compact-fascicular, incrusted with sand. Peridium pale ochraceous to yellowish brown with distinct minute, flattened, irregularly rounded scales, towards the base often arranged in concentric zones. Scales concolourous with or darker than the rest of the peridium. A smooth or minutely furfuraceous peridium may occur in very young fruitbodies. The peridium is thin (appr. $1 \mathrm{~mm}$ ) but rather tough, at maturity irregularly opening in the top area; old fruitbodies become entirely cup-shaped. Peridial hyphae \pm hyaline, thin-walled, 4-6 $\mu \mathrm{m}$ in diametre, with clamps. Mature gleba greyish brown, sometimes with olivaceous tinges. Spores globose-subglobose, (7-)9-11(-15) $\mu \mathrm{m}$ in diametre, brown, with a reticulate wall. The reticulum is complete. The spores vary greatly in size even in one and the same fruitbody (see below). 


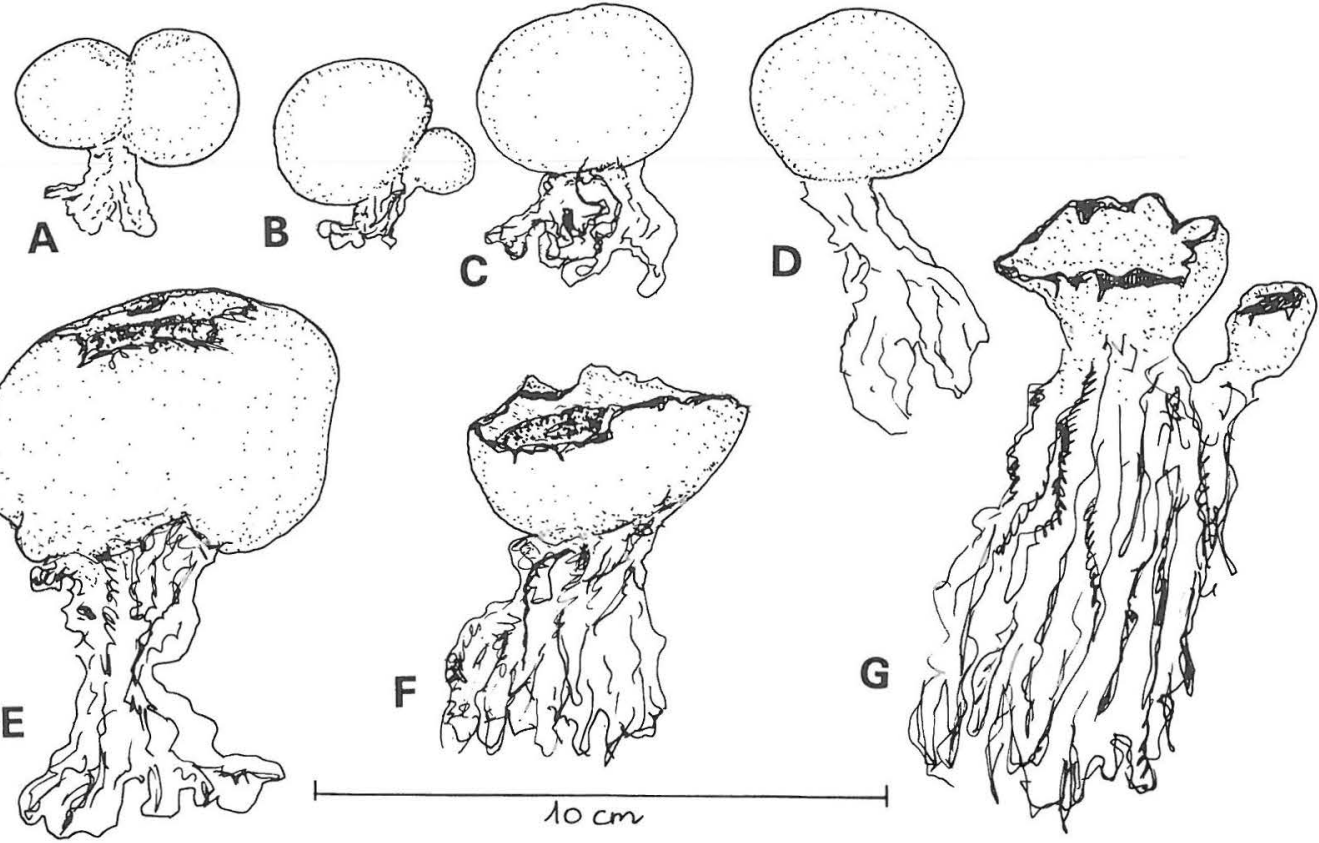

Fig. 2. Scleroderma septentrionale. Fruitbodies in different stages of development. (A-D. Finland, St, Pori, Yyteri, M. Eriksson (TUR; A) 6.VIII.1964, B) 30.VIII.1962, C) 4.IX.1964, D) 5.IX.1964), E) Finland, U, Hanko, Storviken, 2.IX.1965 M. Eriksson (TUR), F) Finland, V, Nauvo, Sandviken, 29.IX.1963 M. Eriksson (TUR). G) Finland, OP, Ii, Ulkokrunni, 5.IX.1965 T. Ulvinen (OULU).

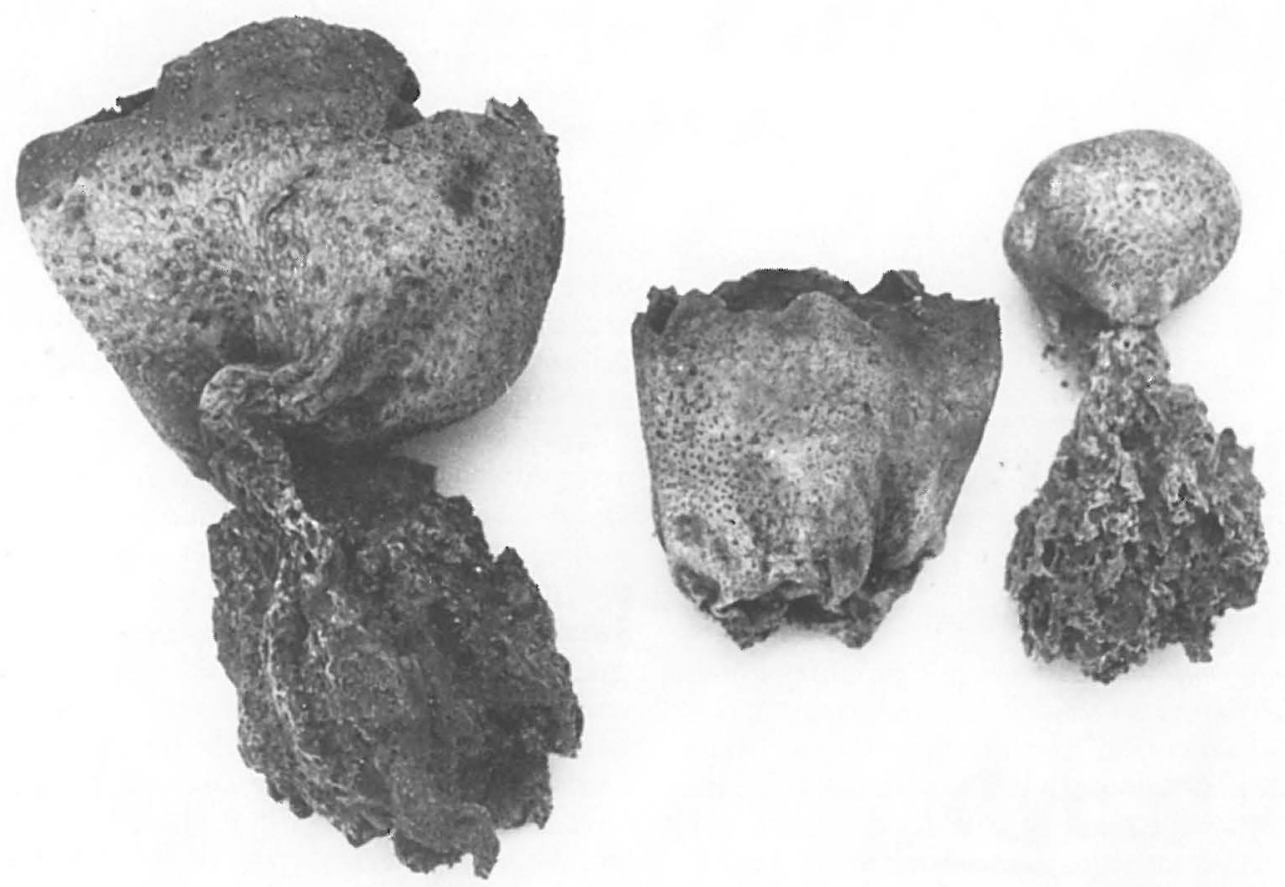

Fig. 3. Scleroderma septentrionale. Holotypus. Photo P.I. Wåhleman. 
Material studied: Finland. Varsinais-Suomi, Nauvo, Sandö, 29.IX.1962 M. Eriksson (TUR 156, 166, 184); Korppoo, Ängsö, 21.VIII.1963 I. Kukkonen \& O. Ravanko (TUR 151). Uusimaa, Hanko, Storviken, 23.XII.1964, 2.IX.1965, Kolaviken, 22.VIII.1964, 18.IX.1970, Henriksberg, 11.IX.1964 M. Eriksson (14 specimens TUR); Helsinki, Vuosaari, south shore of Kallvikinniemi, 19.IX.1971 L. Hämet-Ahti 2336a (H). Satakunta, Pori, Yyteri, 1.X.1960, 28.VIII.1962, 30.VIII.1962, 2.IX.1962, 6.VIII.1964, 4.IX.1964, 5.IX.1964, 15.VIII.1965, 14.IX.1965, 14.X.1965, 31.VIII.1970 M. Eriksson (19 specimens TUR, OULU). Pohjois-Savo, Kuopio, Hietasalo, 1977 L. Hakala (TUR 307). Keski-Pohjanmaa, Kokkola, Laajalahti, 13.IX.1981 R. Storbacka (OULU); Kalajoki, 10.IX.1863 M. Eriksson (TUR 177, 186, OULU). Oulun Pohjanmaa, Haukipudas, Isoniemi, Saukkoperä, 12.10.1965 T. Ulvinen (OULU), 18.IX.1984 T. Ulvinen, E. Ohenoja, K. Kalamees (OULU, type); Oulunsalo, Koppana 18.IX.1963 M. Eriksson (TUR 161, 172, 189, OULU); Simo, Hepola, 21.IX.1963 M. Eriksson (TUR 146); Ii, Ulkokrunni, Pohjanharju, 5.IX.1965 T. Ulvinen (OULU). Perä-Pohjanmaa, Kemi, Ajos, 20.IX.1963 M. Eriksson (TUR 183, 185, 187, OULU), 22.IX.1984 M. Kamula (OULU). Denmark. Anholt, Ørkenen, 15.X.1991 C. Lange (C. Lange private herbarium). Sweden. Skåne, Löderup sn, Sandhammaren, 1946 O. Andersson (LD), 6.X.1946 O. Andersson (LD); Ystad, Saltsjöbad, 19- O. Andersson (LD). Uppland, Djurö sn, Sandhamn, 4.XI.1985 J. Nitare (S). Hälsingland, Hudiksvall, Hölick, 4.IX.1986 J. Nitare (S); Gnarp sn, Gnarp 4.IX.1986 J. Nitare (S), Moningssand, 4.IX.1986 J. Nitare (S). Ångermanland, Grundsunda sn, Saluböle, 7.IX.1986 J. Nitare (S); Härnösand, Hemsön, Arboretum Drafle, 20.IX.1970 A. Strid 14884 \& O. Eriksson (UME 26396). Västerbotten, Lövånger sn, Bjuröklubb, 9.IX.1986 J. Nitare (S), Nordingrå sn, Storsanden, 18.IX.1975 O. Eriksson (UME 26605a, b, colour slides), Obbolalandet, 20.VIII.1971 L. Hjortsberg (UME 26602). Norrbotten, Nederkalix sn, Båtskärsnäs, 11.IX.1986 J. Nitare (S), Båtskärsnäs, Frevisören, 2.IX.1972 A. Strid 10311 (UME, M.J.); NedertorneåHaparanda sn, Santasaari, 12.IX.1986 J. Nitare (S); Nedertorneå, Sandskäret, 22.VIII.1952 E. Julin, Fungi Exs. Suecici 2258 (S, UPS); Piteå, Piteâ havsbad, 19.IX.1986 J. Nitare (S), Piteå archipelago, Stor-Rebben, 3.IX.1930 Th. Arwidsson (S), Stenskär, IX.1930 Th. Arwidsson (S); Nederluleå, N of Kallax, IX.1970 R. Keskküla (S). Iceland. Suðvesturland, Gullbringusysla, Helgafell, 21.IX.1980 Hörður Kristinsson \& Pétur Sigurðsson (REYK 45387).

\section{Ecology and distribution}

Scleroderma septentrionale is a psammophilous species found on sand dunes and sandy heaths along the coasts of North Europe (Fig. 6). There is a concentration of localities along the Baltic and Bothnian coasts of Finland and Sweden. Isolated occurrences are known from the island Anholt in Kattegatt (Denmark) and from Iceland. Most occurrences are in the close vicinity of the sea, which possibly has a positive influence by increasing the local humidity and maintaining mild and even temperatures during the autumn. There are only two records from inland localities, viz. from Finland, Pohjois-Savo, Kuopio, and Iceland, Helgafell (see list of specimens). In the latter case the locality is situated in the southwestern area of Iceland, where there is a strong maritime influence. As for the Kuopio locality, the site was a sandy lake shore with pine (L. Hakala, pers. comm.).

The distribution and ecological requirements of $S$. septentrionale could be compared with those of the ascomycete Geoglossum arenarium (Rostr.) Lloyd as presented by Nitare (1982). G. arenarium is a presumptive symbiont with Empetrum and is frequently encountered in the same localities as S. septentrionale (J. Nitare, pers. comm.).

The fruitbodies of $S$. septentrionale occur half buried in bare sand among Arctostaphylos uva-ursi, Empetrum nigrum, Lathyrus japonicus var. maritimus, Leymus arenarius and Rumex acetosella, in south Sweden also among Ammophila arenaria. In one locality (Anholt) the fruitbodies appeared among Salix repens. The general composition of the flora indicates rather low $\mathrm{pH}$ values. Scattered pine trees (Pinus sylvestris) seem to have been present in most of the localities and mycorrhiza was suspected already by Rautavaara (1953), who first recorded S. septentrionale (as S. bovista) from Finland. Eriksson (1964), who investigated the fungi on Finnish sand dunes, recorded it (as S. bovista) from several places and always in the root zones of the pine. Since Pinus is not indigenous in Iceland, the occurrence there may indicate symbiotic relations also with other plants (Empetrum?).

The northern distribution of this taxon was noted already by Arwidsson (1936), who first found it and regarded it as a sand form of $S$. aurantium (=S. citrinum). Andersson (1950) reported the same species as $S$. bovista from South Sweden but considered it a facultative sand fungus having a southern distribution more or less coinciding with that of Quercus robur. Rautavaara (1953) and Eriksson (1964) identified their findings on Finnish sand dunes as $S$. bovista referring to Andersson (1950). They both noted that Andersson was mistaken in his suggestion that $S$. bovista had a southern distribution in Fennoscandia (which it in fact has). 


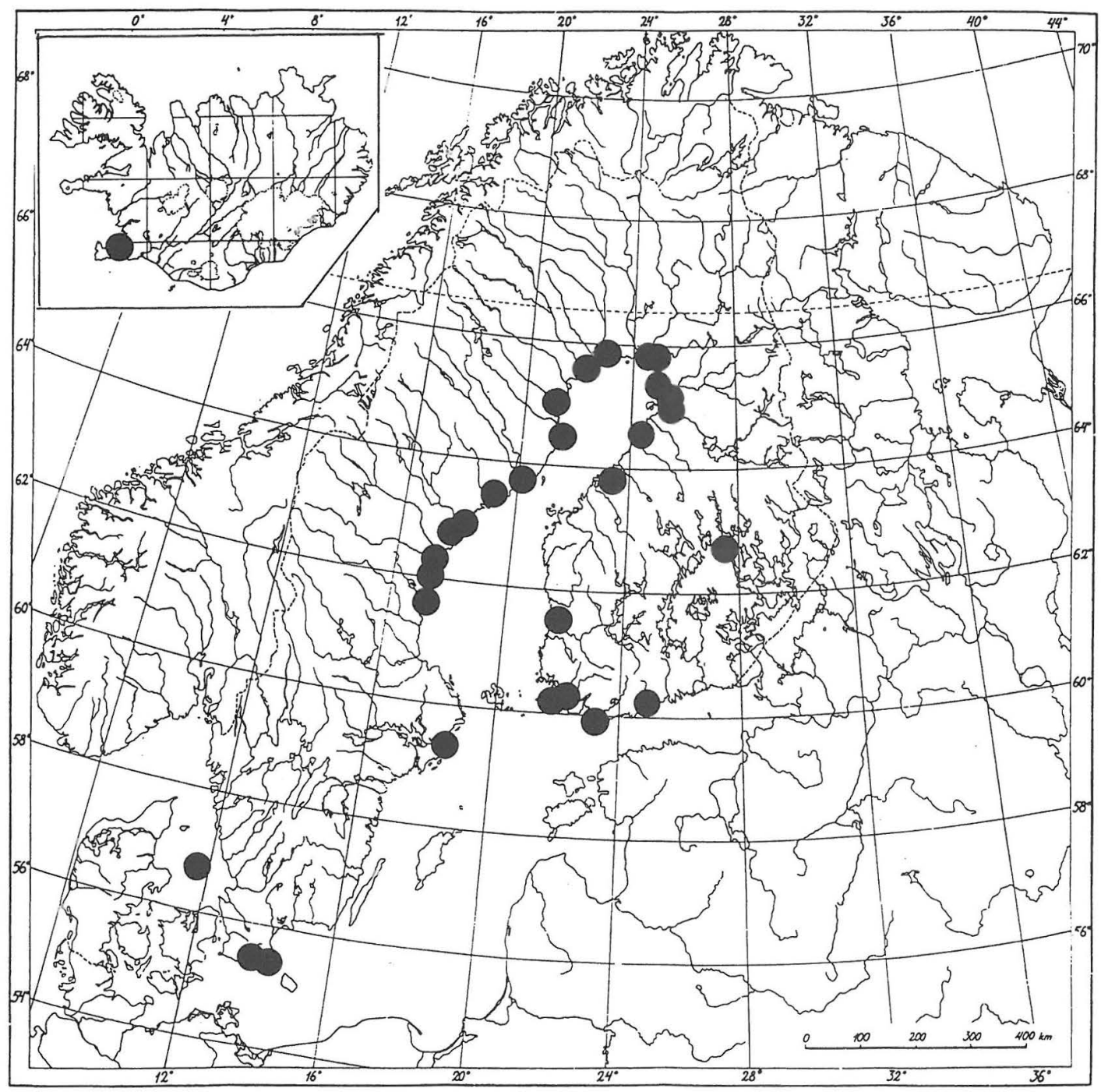

Fig.4. Known distribution of Scleroderma septentrionale.

There seem to be some reports from continental Europe which may relate to $S$. septentrionale. Records of Scleroderma from sand dunes of the Atlantic and North Sea coasts all seem to refer to S. bovista (or S. meridionale in southern areas), but Šebek $(1953,1964)$ reported findings on sand dunes in Bohemia of a taxon he identified as $S$. aurantium (Vaill.) Pers. var. macrorhizum Fr. According to his description it may be close to or even identical with S. septentrionale. Šebek's collections were not examined for this paper. In North America the occurrence of a large sand dune Scleroderma in the Great Lakes Region is noteworthy. This fungus was beautifully illustrated by Smith (1951) as a doubtful S. aurantium and was later (Smith \& Smith 1973) reported as S. macrorhizon Wallroth based on Guzmán's interpretation of the latter. Later Demoulin (1974) found it to be identical with $S$. meridionale, a species described from the Mediterranean and Atlantic regions of South Europe and North Africa. In the light of the present studies a reinvestigation of the American samples of $S$. meridionale from the Great Lakes region is proposed. 
Table 1. Diagnostic characters in Scleroderma sect. Scleroderma.

\begin{tabular}{|c|c|c|c|c|}
\hline & $\begin{array}{l}\text { Scleroderma } \\
\text { citrinum }\end{array}$ & $\begin{array}{l}\text { Scleroderma } \\
\text { bovista }\end{array}$ & $\begin{array}{l}\text { Scleroderma } \\
\text { septentrionale }\end{array}$ & $\begin{array}{l}\text { Scleroderma } \\
\text { meridionale }\end{array}$ \\
\hline pseudostipe & $\begin{array}{l}\text { absent; fruitbody } \\
\text { sessile }\end{array}$ & $\begin{array}{l}\text { short - prominent; } \\
\text { rhizomorphic - } \\
\text { fasciculose }\end{array}$ & $\begin{array}{l}\text { prominent; } \\
\text { fasciculose- } \\
\text { compact }\end{array}$ & $\begin{array}{l}\text { prominent - } \\
\text { compact }\end{array}$ \\
\hline $\begin{array}{l}\text { peridium } \\
\text { consistency }\end{array}$ & $\begin{array}{l}\text { thick, } 1-4 \mathrm{~mm} \\
\text { though }\end{array}$ & $\begin{array}{l}\text { thin, appr. } 1 \mathrm{~mm} \text {, } \\
\text { fragile }\end{array}$ & $\begin{array}{l}\text { thin, appr. } 1 \mathrm{~mm} \text {, } \\
\text { fragile to tough }\end{array}$ & $\begin{array}{l}\text { thick, }>1 \mathrm{~mm} \text {, } \\
\text { tough }\end{array}$ \\
\hline peridium & pale brown & pale yellowish & pale brown & pale brown \\
\hline colour & to yellowish & to greyish brown & to yellowish brown & to golden brown \\
\hline $\begin{array}{l}\text { peridium } \\
\text { ornamentation }\end{array}$ & $\begin{array}{l}\text { coarse scales } \\
\text { all over }\end{array}$ & $\begin{array}{l}\text { smooth, sometimes } \\
\text { minute scales at apex }\end{array}$ & $\begin{array}{l}\text { minute scales } \\
\text { all over }\end{array}$ & furfuraceous \\
\hline spores $(\mu \mathrm{m})$ & $\begin{array}{l}(8) 10-11(13) \\
\text { incomplete } \\
\text { reticulum }\end{array}$ & $\begin{array}{l}(8) 9-11(13) \\
\text { complete } \\
\text { reticulum }\end{array}$ & $\begin{array}{l}(7) 9-11(15) \\
\text { complete } \\
\text { reticulum }\end{array}$ & $\begin{array}{l}(9) 10-13(14) \\
\text { complete } \\
\text { reticulum }\end{array}$ \\
\hline dehiscence & apical, irregular & apical, irregular & apical, irregular & $\begin{array}{l}\text { apical, irregular - } \\
\text { stellate }\end{array}$ \\
\hline ecology & $\begin{array}{l}\text { on acid soil in } \\
\text { woodland \& } \\
\text { heathland }\end{array}$ & $\begin{array}{l}\text { woodlands, } \\
\text { meadows, sand } \\
\text { dunes; neutrophilic }\end{array}$ & $\begin{array}{l}\text { on sand dunes } \\
\text { and sandy } \\
\text { heathland }\end{array}$ & $\begin{array}{l}\text { forests on sandy } \\
\text { soil, verges, } \\
\text { clearings, sand dunes }\end{array}$ \\
\hline $\begin{array}{l}\text { distribution } \\
\text { in Europe }\end{array}$ & $\begin{array}{l}\text { temperate \& } \\
\text { hemiboreal; north } \\
\text { to appr } 62^{\circ}\end{array}$ & $\begin{array}{l}\text { temperate \& } \\
\text { hemiboreal, isolated } \\
\text { occurences in } \\
\text { southern part of } \\
\text { boreal zone; north } \\
\text { to } 61^{\circ} \text { ( } 64^{\circ} \mathrm{N} \text { on } \\
\text { Norwegian coast) }\end{array}$ & $\begin{array}{l}\text { hemiboreal - } \\
\text { boreal, occasional } \\
\text { records in temperate } \\
\text { zone; north to } \\
65^{\circ} 50^{\prime}\end{array}$ & $\begin{array}{l}\text { Mediterranean \& } \\
\text { Atlantic region, } \\
\text { north to } 47^{\circ}\end{array}$ \\
\hline
\end{tabular}

\section{Discussion}

Material of a rooted Scleroderma matching the concept of $S$. septentrionale was distributed in Fungi Exsiccati Suecici (2258) with the following note: "It is with some doubt that this collection is distributed as $S$. aurantium but it seems to be only a luxuriant form caused by the habitat (sandy hose)".

Guzmán (1970) designated the specimen in FES as neotype of Scleroderma macrorhizon Wallroth and choose this name for any Scleroderma with a prominent pseudostipe and reticulate spores. Later Demoulin (1974) showed that the holotype of $S$. macrorhizon, which had been unknown to Guzmán, in fact belonged to typical $S$. bovista. This meant that Wallroth's epithet had to be rejected for the northern taxon. Fries (1829) described S. vulgare var. macrorhizum, which should also be taken into consideration. According to Demoulin (1974) there is, however, no authentic material at hand and the name has to be rejected as a nomen dubium. Subsequently, a new name had to be chosen for the sand dune Scleroderma of north Europe. The epithet septentrionale refers to its distribution in northerly areas, which makes it a unique member of the genus.

$S$. septentrionale is closely related to $S$. bovista and $S$. citrinum (see Table 1). It differs in the presence of a prominent pseudostipe and by having a thin and distinctly ornamented peridium. It also resembles $S$. meridionale, which, however, has a thick peridium with a furfuraceous surface. Since the sand dune Scleroderma of the Great Lakes Region was synonymized with S. meridionale by Demoulin (1974), material of 
that species originating from the Mediterranean area was studied. It was found to deviate from $S$. septentrionale in having a much thicker and smooth-furfuraceous peridium with brighter colours as well as a more compact pseudostipe.

The prominent pseudostipe in S. septentrionale is an adaptation to the sandy habitat. $S$. bovista is usually provided with a rather short pseudostipe, which may, however, be rather prominent when the fungus is met with in sandy or gravelly places. The peridium in $S$. bovista is, however, \pm smooth or merely cracked or minutely scaly at the top of the fruitbody. S. citrinum only rarely shows tendencies to form a short pseudostipe, also when growing in sandy situations. In S. septentrionale the size of the spores varies significantly even within a single specimen, a tendency which seems more pronounced than in the related species. The explanation is obscure. In one sample Demoulin (1974) suggested a disturbed maturation process caused by its very northern locality $\left(65^{\circ} \mathrm{N}\right)$. This theory does not seem to hold true since $S$. septentrionale collected in the south of Scandinavia (where the climate is more favourable) shows the same variability. It must, however, be kept in mind that spore size is a well known problem in Scleroderma, the spores ripening and reaching their final dimension with the help of nursing hyphae after the autolysis of the basidia (Guzmán 1970).

Acknowledgements. I am much indebted to Dr. V. Demoulin (Liège) and Dr. T. Ulvinen (Oulu) for reading and proposing improvements to the manuscript and to Dr. N. Lundqvist (Storvreta) for revising the Latin diagnosis. I also wish to express my sincere gratitude to the patient curators at the herbaria of $H, L D$, OULU, REYK, S, TUR, UME and UPS. Special thanks go to Dr. $\AA$ A. Strid (Stockholm), Dr. H. Kristinsson (Akureyri), Dr. G. Eyjólfsdóttir (Akureyri), Dr. S. Huhtinen (Turku), Mr. J. Nitare (Huskvarna), Dr. R. Courtecuisse (Lille), Mr. J. Mornand (Angers), Dr. P. Lassen (Lund), Mr. S. Svensson (Lund), Dr. C. Lange (Århus), Dr. S. Ryman (Uppsala), Dr. O. Skifte (Tromsø) and Mr. B. Oldhammer (Mora) for valuable information and discussions and for lending me material and photos of Scleroderma. Mr. P.-I. Wåhleman's (Trollhättan) photographic assistance is also thankfully acknowledged.

\section{References}

Andersson, O. 1950: Larger fungi on sandy grass heaths and sand dunes in Scandinavia. - Bot. Not. Suppl. 2(2): 1-89.

Arwidsson, Th. 1936: Norrländska gasteromycetlokaler. - Bot. Not. 1936:532-538.
Demoulin, V. 1974: Scleroderma meridionale Demoulin et Malençon, the correct name for the large Scleroderma of Great Lakes sand dunes. - Michigan Bot. 13:68-72.

Eriksson, M. 1964: Larger fungi on dunes in Finland. Rep. Kevo Subarctic Res. Stat. 1:149-154.

Fries, E. 1829: Systema mycologicum III. Lundæ.

Guzmán, G. 1970: Monografía del género Scleroderma Pers. emend Fr. (Fungi. Basidiomycetes). - Darwiniana 16:233-407.

Mossberg, B., Stenberg, L. \& Ericsson, S. 1992: Den nordiska floran. Stockholm.

Nitare, J. 1982: Geoglossum arenarium, sandjordtunga ekologi och utbredning i Sverige. - Svensk Bot. Tidskr. 76:349-357.

Rautavaara, T. 1953: Juuritryffeli (Scleroderma bovista Fr.) lentohiekassa Pohjois-Suomessa. - Karstenia 2:50.

Šebek, S. 1953: Monograph of the central European species of the genus Scleroderma Pers. - Sydowia 7:158-190.

Šebek, S. 1964: Břichatkovité houby písečné přesypové oblasti ve středním Polabi. - Ceská Myk. 18:109 116.

Smith, A. H. 1951: Puffballs and their allies in Michigan. - 131 pp. Ann Arbor.

Smith, H. V. \& Smith, A. H. 1973: How to know the non-gilled fleshy fungi. - $402 \mathrm{pp}$. Dubuque.

Received on 4 February 1998 